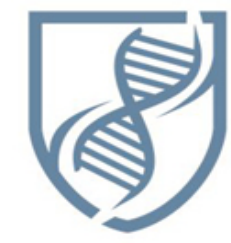

Journal of Bioscience and Applied Research
JBAAR

WWW.JBAAR.ORG

\title{
Impact of seasonal changes on the quality of water and fish from Abu Za'baal Lakes
}

\author{
Hala Elshahat Ghannam ${ }^{1}$, Abdelrahman Said Talab ${ }^{2 *}$ and Abdel-Samie Abd El-Hamide Elewa ${ }^{3}$ \\ ${ }^{1}$ Pollution Laboratory, Inland Water and Lakes Division, National Institute of Oceanography and Fisheries (NIOF), Cairo, Egypt \\ ${ }^{2}$ Fish Processing and Technology Laboratory, Fisheries Division, National Institute of Oceanography and Fisheries (NIOF), Cairo, Egypt \\ ${ }^{3}$ Chemistry Laboratory, Inland Water and Lakes Division, National Institute of Oceanography and Fisheries (NIOF), Cairo, Egypt
}

(E-mail: corresponding author: Abdelrahman_saidh@yahoo.com)

\begin{abstract}
Physicochemical characteristics and concentrations of some heavy metals of water and two fish species in Abu Za'baal lakes during the period from summer 2012 to spring 2013 were investigated. The physicochemical characteristics of water and fish were proved to be within the permissible levels during different seasons. However, heavy metals levels exceed the permissible limits in water samples, and also $\mathrm{Pb}$ in fish muscles. The concentrations of heavy metals were significantly higher in water and fish muscles during summer and the metal concentrations in water were present in the following order: $\mathrm{Mn}>\mathrm{Pb}>\mathrm{Zn}>$ $\mathrm{Cu}>\mathrm{Cd}$, while those of fish were found in the order of: $\mathrm{Zn}>$ $\mathrm{Mn}>\mathrm{Pb}>\mathrm{Cu}>\mathrm{Cd}$. Proximate composition of two fish species showed a significant variation $(\mathrm{p}<0.05)$ during different seasons. TVBN, TMA, TBA and TPC were under the permissible limits as acceptability for raw fish, moreover heavy metals in water and fish muscle did not exhibit any effect on proximate composition and physicochemical characteristics of fish muscles.
\end{abstract}

Keywords: Heavy metals; TBA; TMA; TVB-N.

\section{Introduction}

Abu Za'baal lakes are considered as artificial Lakes, which recently created after stone pits stopped in the quarries and received seepage and ground water from the surrounding area particularly from Ismailia canal, Baher ElBakar drain and cultivated land. These Lakes are located in the north of El-Qalubia Governorate at Abu Za'baal City,
$30 \mathrm{kms}$ southwest of Cairo which were created owing to fracture and extract of the Basalt rocks. They are three closed basins that filling during the fifth decade (first Lake), the eighth decade (second Lake) and the ninth decade (third Lake), besides small Lake in a filling phase. These lakes occupy the area between latitudes $30^{\circ} 16.62^{\prime}$ and $30^{\circ} 17.58^{\prime} \mathrm{N}$ and longitudes $31^{\circ} 20.90^{\prime}$ and $31^{\circ} 21.69^{\prime}$ $\mathrm{E}$ and cover an area of about $608 \times 10^{3} \mathrm{~m}^{2}$ (about 150 feddan) and their total water volume is about $5234.075 \times 10^{3}$ $\mathrm{m}^{3}$. There was a great increase in depth of the first Lake northward $(0.6-20 \mathrm{~m})$, with an average of $10.2 \mathrm{~m}$. The water depth of the second and third Lakes fluctuated between 2.9-7.6 and 0.8-7.1 $\mathrm{m}$ with an overall average of 6.1 and $5.7 \mathrm{~m}$, respectively (Abd-Ellah, 2003 and AlGhanim, 2012).

Toxic heavy metals compounds affect negatively people's health. Minute amounts these metals compounds are necessary to support life, while larger amounts become toxic and create significant health hazards. Human exposure to heavy metals has risen dramatically over the last few decades as a result of the exaggerated progress in the industrial processes (Shantakumari, et al., 2012). The most important heavy metals from the water pollution point of view are $\mathrm{Zn}, \mathrm{Cu}, \mathrm{Pb}$. Cd, $\mathrm{Hg}$, Ni and $\mathrm{Cr}$. Some of these metals (e.g. $\mathrm{Cu}$. Ni, $\mathrm{Cr}$ and $\mathrm{Zn}$ ) are essential trace metals to living organisms, but become toxic at higher concentrations. Others such as $\mathrm{Pb}$ and $\mathrm{Cd}$ have no known biological function, but still toxic (Dudka and Adriano, 1997\& Ghannam, et al., 2015).

Fish freshness is the most important single criterion for judging the quality of the majority of fish and fishery products. Loss of freshness followed by spoilage is a 
complex combination of microbiological, chemical and physical processes. Several chemical parameters have been proposed to establish a freshness scale using techniques such as volatile organic acids determination, fat and protein changes, microbiological and sensory changes (PedrosaMenabrito and Regenstein 1990). The quality of fish and fishery products has become a major concern in fish industry all over the world (Huss et al., 2003). Fish, being one of the exceptionally perishable foods and as a result of globalization of food trade fish products tend to be more susceptible to rejection due to poor quality especially if the initial raw materials are of poor quality despite the technological developments in fish production (FAO, 2009; Huss et al., 2004). Few studies have been reported on the effect of seasonal changes on the quality and freshness properties of freshwater fish.

The present study aims to evaluate the quality of both water and two selected fish species collected from Abu Za'baal lakes during 2012-2013, and to examine the seasonal fluctuations in $\mathrm{Zn}, \mathrm{Cu}, \mathrm{Mn}, \mathrm{Cd}$ and $\mathrm{Pb}$ concentrations in both water and fish beside their effect on the proximate composition of selected fish species. These findings are important, not only for clarifying the present status of heavy metals pollution levels of Abu Za'baal lakes but also for the development of rational management plans.

\section{Materials and Methods}

\section{Study area}

Abu Za'baal lakes (Fig. 1) $\left(30^{\circ} 17 \mathrm{~N}, 31^{\circ} 20 \mathrm{E}\right)$ are located on the perimeter of Cairo in an area where basalt mining was done by blasting in open pits. In 1992, a severe earthquake occurred and the basin began to fill with water, which rose at a rate of 2-3 m per year, forming a lake about $3 \mathrm{~km}$ length, $1.5 \mathrm{~km}$ width with a maximum depth of $25 \mathrm{~m}$ and an average depth of $18 \mathrm{~m}$. In this arid environment, the lakes do not receive surface inflow. Beside the main lake, three smaller lakes have formed subsequently and the amalgamations of all these lakes are possible in the next few years (Al-Ghanim, 2012).

\section{Sampling program}

Water and fish samples were collected during four successive seasons from summer 2012 to spring 2013. The samples were collected from four different stations of $\mathrm{Abu}$ Za'baal lakes (Fig. 1), two in the first lake and one at the middle of each of second and third sampling sites.

\section{Water samples}

Water samples were collected from $60 \mathrm{~cm}$ depth using polyethylene bottles with capacity of one liter. For heavy metals analysis water samples were collected in one-liter plastic bottles and preserved with $5 \mathrm{ml}$ concentrated nitric acid (APHA, 1998). The samples were preserved in an icebox and returned immediately to the laboratory.

The $\mathrm{pH}$ value, temperature and electrical conductivity were measured in the field, using Hydrolab, Model "Multi 340I/SET". The chemical parameters (DO, BOD COD) and heavy metals ( $\mathrm{Zn}, \mathrm{Cu}, \mathrm{Mn}, \mathrm{Cd}, \mathrm{Pb})$ concentrations were determined in water samples according to the methods described in APHA, (1998).

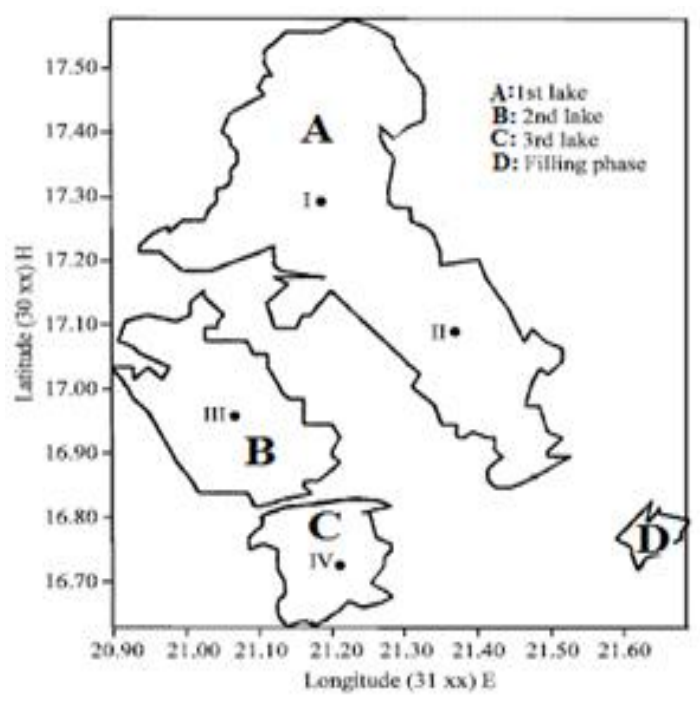

Figure 1. Map of Abu Za'baal lakes (ponds)

\section{Fish samples}

Twenty fresh fish samples of Nile tilapia (Oreochromis niloticus) and twenty catfish (Clarias gariepinus) were collected seasonally from summer 2012 to spring 2013 and transposed using ice-box to the pollution laboratory, National Institute of Oceanography and Fisheries, ElKanater El-Khiria city, El-Qalubia Governorate, Egypt for the analysis. Mean weights and lengths of collected Nile tilapia and Catfish samples were $(349 \pm 3.61 \mathrm{~g}$ and $25.50 \pm 2.29 \mathrm{~cm})$ and $(695 \pm 7.07 \mathrm{~g}$ and $52.25 \pm 2.47 \mathrm{~cm})$, respectively. Fish samples were re-washed thoroughly with potable water then beheaded and dissected to obtain muscles.

The moisture, protein, lipid, ash, total volatile basic nitrogen (TVB-N), trimetylamine (TMA) and thiobarbituric acid (TBA) values were determined using the method of AOAC (2002). Total plate counts (TPC) determined according to (APHA, 1998). The fish samples were digested according to Meche et al., (2010). The concentrations of heavy metals ( $\mathrm{Zn}, \mathrm{Cu}, \mathrm{Mn}, \mathrm{Cd}$ and $\mathrm{Pb}$ ) were measured using Inductively Coupled Plasma Optical Emission Spectrometry (ICP-OES) Model Perkin Elmer Optima 3000.

\section{Statistical Analysis}

Analysis of Variance (ANOVA) was used to determine differences between various sets of data. Significant differences are stated at $\mathrm{P}<0.05$.

\section{Results}

\section{Water analysis}

Physicochemical parameters in $\mathrm{Abu}$ Za'baal lakes water from summer 2012 to spring 2013 are shown in Table (1). 
Table 1. Physicochemical parameters ${ }^{\mathrm{a}}$ in Abu Za'baal lakes water from summer 2012 to spring 2013

\begin{tabular}{|c|c|c|c|c|c|}
\hline Parameters & Stations & Summer & Autumn & Winter & Spring \\
\hline \multirow[t]{4}{*}{ Air temp. ${ }^{\circ} \mathrm{C}$} & $\mathrm{I}$ & $31.30 \pm 0.06$ & $25.40 \pm 0.92$ & $18.20 \pm 0.31$ & $22.40 \pm 0.76$ \\
\hline & II & $31.70 \pm 0.51$ & $25.60 \pm 0.57$ & $17.80 \pm 0.25$ & $22.50 \pm 0.40$ \\
\hline & III & $31.50 \pm 0.38$ & $25.40 \pm 0.75$ & $18.30 \pm 0.42$ & $22.60 \pm 0.79$ \\
\hline & IV & $30.80 \pm 0.77$ & $25.30 \pm 0.82$ & $17.70 \pm 0.33$ & $22.40 \pm 0.12$ \\
\hline \multirow[t]{4}{*}{ Water temp. ${ }^{\circ} \mathrm{C}$} & $\mathrm{I}$ & $30.80 \pm 0.26$ & $24.10 \pm 0.37$ & $17.50 \pm 0.11$ & $20.90 \pm 0.83$ \\
\hline & II & $31.20 \pm 0.85$ & $24.70 \pm 0.21$ & $16.60 \pm 0.18$ & $20.20 \pm 0.75$ \\
\hline & III & $31.30 \pm 0.62$ & $24.30 \pm 0.54$ & $17.10 \pm 0.39$ & $20.50 \pm 0.80$ \\
\hline & IV & $30.70 \pm 0.25$ & $24.60 \pm 0.71$ & $16.30 \pm 0.21$ & $20.10 \pm 0.13$ \\
\hline \multirow[t]{4}{*}{$\mathrm{EC}(\mu \mathrm{s} / \mathrm{cm})$} & $\mathrm{I}$ & $5110.20 \pm 0.26$ & $3320.00 \pm 0.44$ & $3780.00 \pm 0.36$ & $6420.00 \pm 0.12$ \\
\hline & II & $4130.10 \pm 0.90$ & $3400.00 \pm 0.84$ & $3820.00 \pm 0.74$ & $5510.00 \pm 0.79$ \\
\hline & III & $415.20 \pm 0.45$ & $239.00 \pm 0.17$ & $379.00 \pm 0.21$ & $429.00 \pm 0.18$ \\
\hline & IV & $420.10 \pm 0.17$ & $271.00 \pm 0.54$ & $333.00 \pm 0.11$ & $453.00 \pm 0.27$ \\
\hline \multirow[t]{4}{*}{$\mathrm{pH}$ value } & $\mathrm{I}$ & $7.70 \pm 0.52$ & $7.90 \pm 0.91$ & $7.80 \pm 0.06$ & $7.90 \pm 0.31$ \\
\hline & II & $7.90 \pm 0.80$ & $7.80 \pm 0.67$ & $7.50 \pm 0.12$ & $7.70 \pm 0.15$ \\
\hline & III & $8.50 \pm 0.41$ & $7.60 \pm 0.21$ & $7.70 \pm 0.28$ & $8.20 \pm 0.33$ \\
\hline & IV & $8.20 \pm 0.15$ & $7.60 \pm 0.33$ & $7.80 \pm 0.15$ & $7.80 \pm 0.54$ \\
\hline \multirow[t]{4}{*}{ DO (mg/l) } & $\mathrm{I}$ & $6.80 \pm 0.20$ & $8.10 \pm 0.83$ & $8.30 \pm 0.36$ & $7.90 \pm 0.61$ \\
\hline & II & $8.00 \pm 0.74$ & $8.70 \pm 0.51$ & $8.80 \pm 0.24$ & $8.50 \pm 0.14$ \\
\hline & III & $7.20 \pm 0.62$ & $7.50 \pm 0.31$ & $7.80 \pm 0.37$ & $7.60 \pm 0.72$ \\
\hline & IV & $7.80 \pm 0.94$ & $8.10 \pm 0.28$ & $9.50 \pm 0.28$ & $9.30 \pm 0.92$ \\
\hline \multirow[t]{4}{*}{ BOD (mg/l) } & I & $4.70 \pm 0.75$ & $4.30 \pm 0.22$ & $4.40 \pm 0.48$ & $5.30 \pm 0.05$ \\
\hline & II & $4.90 \pm 0.95$ & $4.50 \pm 0.37$ & $3.80 \pm 0.22$ & $4.50 \pm 0.56$ \\
\hline & III & $6.50 \pm 0.11$ & $5.20 \pm 0.31$ & $4.30 \pm 0.64$ & $5.50 \pm 0.15$ \\
\hline & IV & $4.02 \pm 0.30$ & $4.00 \pm 0.19$ & $3.30 \pm 0.20$ & $5.10 \pm 0.36$ \\
\hline \multirow[t]{4}{*}{ COD (mg/l) } & I & $10.20 \pm 0.52$ & $6.10 \pm 0.35$ & $6.00 \pm 0.15$ & $9.20 \pm 0.55$ \\
\hline & II & $13.40 \pm 0.07$ & $9.20 \pm 0.05$ & $10.50 \pm 0.18$ & $11.10 \pm 0.91$ \\
\hline & III & $15.40 \pm 0.61$ & $9.90 \pm 0.75$ & $10.50 \pm 0.79$ & $12.30 \pm 0.05$ \\
\hline & IV & $13.20 \pm 0.35$ & $6.20 \pm 0.70$ & $6.10 \pm 0.58$ & $7.50 \pm 0.35$ \\
\hline
\end{tabular}

${ }^{\text {a }}$ Values represent the mean of three determinations \pm SD

The present results showed that, air temperatures (7.50- $15.40 \mathrm{mg} / \mathrm{l})$ and decreased to (6.10-10.50 mg/l) ranged from (30.80-31.70), (25.30-25.60), (17.70-18.30) during cold period.

and (22.40-22.60) ${ }^{\circ} \mathrm{C}$ during summer, autumn, winter and spring, respectively, while, water temperatures ranged from (30.70-31.20), (24.10-24.70), (16.30-17.50) and (20.10$20.90)^{\circ} \mathrm{C}$ during the proceeding period, respectively (Table 1). Electrical conductivity of Abu Za'baal lakes water ranged from (271-6420 $\mu \mathrm{s} / \mathrm{cm})$ during different seasons. The highest values were recorded during hot seasons (spring and summer) $415-6420 \mu \mathrm{s} / \mathrm{cm}$, while the lowest values $(217-3820 \mu \mathrm{s} / \mathrm{cm})$ were recorded during cold seasons (autumn and winter). $\mathrm{pH}$ values was found in the alkaline side $(\mathrm{pH}>7.0)$, with the higher values (7.70-8.50) recorded during hot period, while the low values (7.507.90) were obtained in the cold period.

The present results showed that dissolved oxygen during summer, autumn, winter and spring recorded the ranges of (6.80-8.00), (7.50-8.70), (7.80-9.50) and (7.909.30) $\mathrm{mg} / \mathrm{l}$ respectively. The highest values of biochemical oxygen demand at Abu Za'baal lakes were recorded during hot period (4.02-6.50 mg/l) while the lowest values were recorded during cold period (3.30-5.02 $\mathrm{mg} / \mathrm{l})$. Also, the COD values increased during hot period and ranged from

\section{Heavy metals in water}

Heavy metals concentration in water samples of Abu Za'baal lakes are graphically represented in Figures (2-5). The seasonal concentrations of zinc ranged between 0.11 and $0.25 \mathrm{mg} / \mathrm{l}$. The lowest level recorded in winter at station (I) while the highest level recorded in summer at station (III). The copper concentrations ranged between 0.19 and $0.25 \mathrm{mg} / \mathrm{l}$ with the highest level in winter at station (III) and the lowest level in autumn at station (IV). Mn concentrations showed the highest value $(1.50 \mathrm{mg} / \mathrm{l})$ in spring at station (I) and the lowest value $(0.92 \mathrm{mg} / \mathrm{l})$ in winter at station IV. The concentration of Cd showed a wide range of variations between 0.01 and $0.07 \mathrm{mg} / \mathrm{l}$. The highest value of $\mathrm{Cd}$ was recorded in winter at station (III), while the lowest one was in summer at station (I). The concentration of $\mathrm{Pb}$ varied between 0.29 and $0.74 \mathrm{mg} / \mathrm{l}$ and was higher than the permissible limit. 


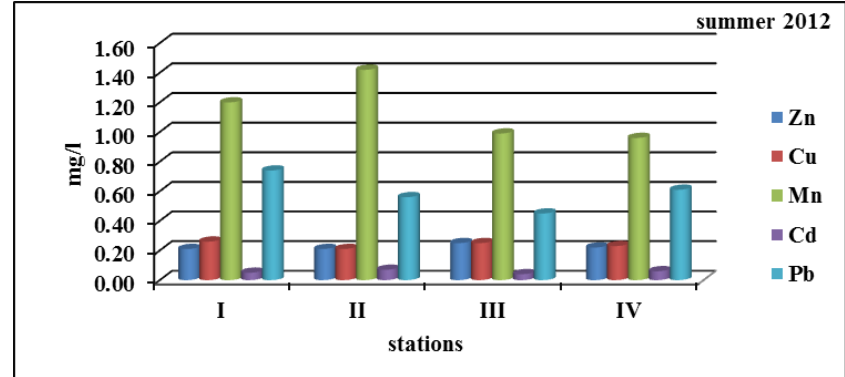

Figure 2. Heavy metals concentrations in water samples from Abu Za'baal lakes during summer 2012

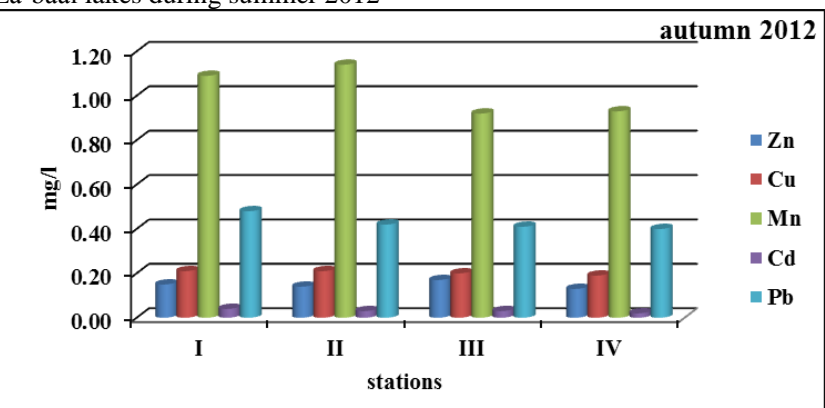

Figure 3. Heavy metals concentrations in water samples from Abu Za'baal lakes during autumn 2012

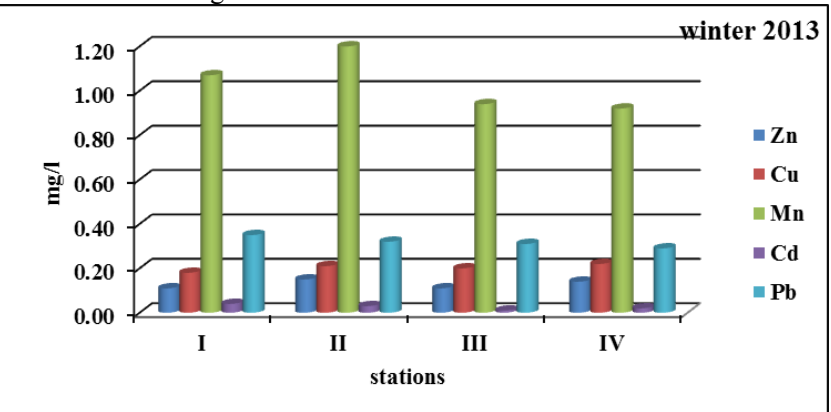

Figure 4. Heavy metals concentrations in water samples from Abu Za'baal lakes during winter 2013

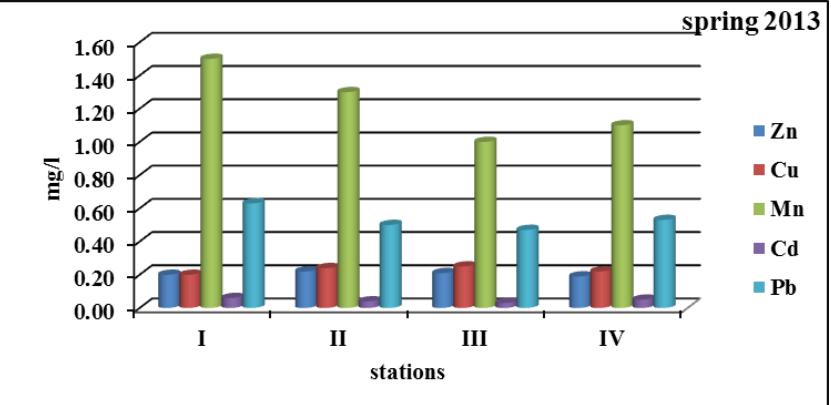

Figure 5. Heavy metals concentrations in water samples from Abu Za'baal lakes during spring 2013

\section{Heavy metals in fish muscles}

The results of heavy metals concentrations in fish muscles of Oreochromis niloticus and Clarias gariepinus during different seasons are given in Figures (6-7). The average concentrations of zinc were 24.91-30.50 $\mu \mathrm{g} / \mathrm{g}$ dry weight for Oreochromis niloticus, compared with 15.12$16.92 \mu \mathrm{g} / \mathrm{g}$ dry weight for Clarias gariepinus. Copper concentrations ranged between 1.01 and $3.41 \mu \mathrm{g} / \mathrm{g}$ dry weight for Oreochromis niloticus and 3.52-5.50 $\mathrm{\mu g} / \mathrm{g}$ dry weight for Clarias gariepinus. Manganese recorded 12.41-
$13.25 \mu \mathrm{g} / \mathrm{g}$ dry weight for Oreochromis niloticus, and 14.25-15.72 $\mu \mathrm{g} / \mathrm{g}$ dry weight for Clarias gariepinus.

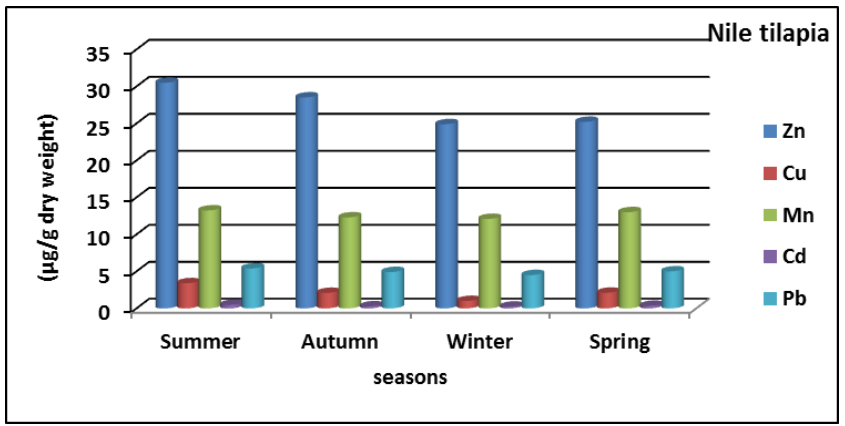

Figure 6. Seasonal changes of heavy metals concentrations in Nile tilapia fish muscles samples from Abu Za'baal lakes

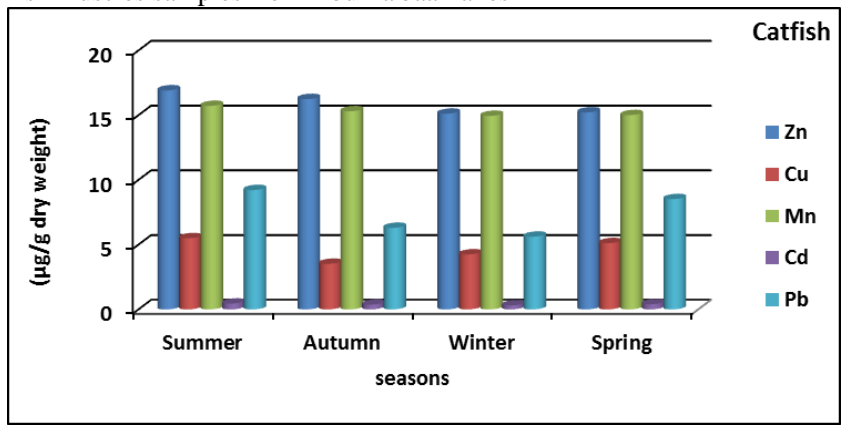

Figure 7. Seasonal changes of heavy metals concentrations in catfish muscles samples from Abu Za'baal lakes.

The average concentrations of cadmium were 0.65 and $0.96 \mu \mathrm{g} / \mathrm{g}$ dry weight for Oreochromis niloticus and (1.30$1.42 \mu \mathrm{g} / \mathrm{g}$ dry weight) for Clarias gariepinus. Lead recorded 4.51 and $5.41 \mu \mathrm{g} / \mathrm{g}$ dry weight for Oreochromis niloticus and (5.62-9.22 $\mu \mathrm{g} / \mathrm{g}$ dry weight) for Clarias gariepinus. A comparison between the present data and those of others was carried out in table (2).

\section{Biochemical quality changes \\ Proximate composition}

Table (3) showed the proximate composition in muscles of Oreochromis niloticus and Clarias gariepinus during different seasons. The average values of proximate composition for Oreochromis niloticus was as follows: moisture content (80.01-80.55\%), protein content (16.50$17.15 \%)$, fat content $(1.20-1.50 \%)$, ash content (1.15$1.36 \%)$ and carbohydrates content (0.04-0.92\%) on wet wt. basis. The average proximate composition of Clarias gariepinus was as follows: moisture content (76.91$78.45 \%)$, protein content $(19.28-20.54 \%)$, fat content (0.95$1.42 \%)$, ash content (1.08-1.19\%) and carbohydrates content (0.04-0.92\%) on wet weight basis.

\section{Physicochemical quality properties of fish}

Physicochemical aspects of Oreochromis niloticus and Clarias gariepinus fish muscles during different seasons of the present study were represented in table (4). The minimum and maximum values of $\mathrm{pH}$ value for Oreochromis niloticus and Clarias gariepinus were (6.857.11) and (6.25-7.01); TVB-N (16.01-17.20) and (18.12- 
19.27) mg/100g; TMA (0.45-0.95) and (0.85-0.91) yde/kg, Total plate count (2.50-2.65) and (2.70-2.90) log 10 $\mathrm{mg} / 100 \mathrm{~g}$; TBA (0.50-0.80) and (0.40-0.76) mg malonaldh- cfu/g sample, respectively (Table 4).

Table 2. Metal concentrations in water $(\mathrm{mg} / \mathrm{l})$ and tissue $(\mu \mathrm{g} / \mathrm{g}$ dry weight) of fishes collected from Abu Za'baal lakes during summer 2012 to spring 2013, and the comparison with permissible upper limits of heavy metals in various standards.

\begin{tabular}{|c|c|c|c|c|c|c|}
\hline Standards & $\mathrm{Zn}$ & $\mathrm{Cu}$ & $\mathrm{Mn}$ & $\mathrm{Cd}$ & $\mathrm{Pb}$ & References \\
\hline \multicolumn{7}{|c|}{ Water (mg/l) } \\
\hline $\begin{array}{l}\text { Egyptian Ministry of Water } \\
\text { Resources and irrigation, law } \\
48 / 1982\end{array}$ & 0.01 & 0.01 & 0.20 & 0.001 & 0.01 & Agrama and El-Sayed (2013) \\
\hline WHO, (2011) & 3 & 2 & 0.40 & 0.003 & 0.01 & Saeed and Mohammed (2012) \\
\hline Maximum values & 0.25 & 0.26 & 1.50 & 0.07 & 0.74 & present study \\
\hline \multicolumn{7}{|c|}{ Fish ( $\mu \mathrm{g} / \mathrm{g}$ dry weight)** } \\
\hline WHO, (1993) & 40 & 5 & 100 & 0.5 & 2 & Authman, et al., (2012) \\
\hline Nile tilapia (maximum values) & 30.50 & 3.41 & 13.25 & 0.48 & 5.41 & present study \\
\hline Catfish (maximum values) & 16.92 & 5.50 & 15.72 & 0.45 & 9.22 & present study \\
\hline
\end{tabular}

Table 3. Proximate chemical composition ${ }^{\mathrm{a}}$ (g/100 g of wet weight) in the muscles of Nile tilapia and catfish collected from Abu Za'baal lakes during summer 2012 to spring 2013

\begin{tabular}{|l|c|c|c|c|c|}
\hline Composition & Species & Summer & Autumn & Winter & Spring \\
\cline { 2 - 6 } Moisture & Nile tilapia & $80.55 \pm 0.75$ & $80.25 \pm 0.57$ & $80.15 \pm 0.77$ & $80.01 \pm 0.61$ \\
\cline { 2 - 6 } & Catfish & $76.91 \pm 0.71$ & $78.45 \pm 0.65$ & $77.69 \pm 0.62$ & $77.40 \pm 0.55$ \\
\hline \multirow{2}{*}{ Protein } & Nile tilapia & $16.50 \pm 0.15$ & $16.95 \pm 0.14$ & $17.15 \pm 0.11$ & $16.85 \pm 0.11$ \\
\cline { 2 - 6 } & Catfish & $20.54 \pm 0.19$ & $19.28 \pm 0.13$ & $19.58 \pm 0.13$ & $19.54 \pm 0.12$ \\
\hline \multirow{2}{*}{ Fat } & Nile tilapia & $1.40 \pm 0.01$ & $1.25 \pm 0.01$ & $1.20 \pm 0.04$ & $1.50 \pm 0.02$ \\
\cline { 2 - 6 } & Catfish & $1.25 \pm 0.03$ & $1.15 \pm 0.02$ & $1.42 \pm 0.21$ & $0.95 \pm 0.01$ \\
\hline \multirow{2}{*}{ Ash } & Nile tilapia & $1.25 \pm 0.02$ & $1.30 \pm 0.01$ & $1.15 \pm 0.02$ & $1.36 \pm 0.03$ \\
\cline { 2 - 6 } & Catfish & $1.15 \pm 0.01$ & $1.08 \pm 0.02$ & $1.14 \pm 0.03$ & $1.19 \pm 0.02$ \\
\hline \multirow{2}{*}{ Carbohydrates } & Nile tilapia & $0.30 \pm 0.20$ & $0.25 \pm 0.15$ & $0.35 \pm 0.11$ & $0.28 \pm 0.19$ \\
\cline { 2 - 6 } & Catfish & $0.15 \pm 0.21$ & $0.04 \pm 0.19$ & $0.17 \pm 0.15$ & $0.95 \pm 0.11$ \\
\hline \multirow{2}{*}{ Calorific values } & Nile tilapia & $79.80 \pm 1.87$ & $80.05 \pm 1.50$ & $80.80 \pm 1.44$ & $82.02 \pm 1.20$ \\
\cline { 2 - 6 } & Catfish & $94.01 \pm 1.75$ & $87.63 \pm 1.60$ & $91.78 \pm 1.39$ & $90.51 \pm 1.88$ \\
\hline
\end{tabular}

${ }^{\text {a }}$ Values represent the mean of three determinations \pm SD

Table 4. Physicochemical properties ${ }^{a}$ (g/100 g of wet weight) in the muscles of Nile tilapia and catfish collected from Abu Za'baal lakes during summer 2012 to spring 2013.

\begin{tabular}{|c|c|c|c|c|c|}
\hline Parameters & Species & Summer & Autumn & Winter & Spring \\
\hline \multirow[t]{2}{*}{ pH value } & Nile tilapia & $6.85 \pm 0.01$ & $7.11 \pm 0.02$ & $7.05 \pm 0.01$ & $6.90 \pm 0.04$ \\
\hline & Catfish & $6.26 \pm 0.03$ & $7.01 \pm 0.01$ & $6.32 \pm 0.01$ & $6.25 \pm 0.02$ \\
\hline \multirow{2}{*}{$\begin{array}{l}\text { TVB-N } \\
\text { (mg/100g flesh) }\end{array}$} & Nile tilapia & $17.20 \pm 0.15$ & $16.25 \pm 0.12$ & $16.01 \pm 0.14$ & $16.15 \pm 0.11$ \\
\hline & Catfish & $19.27 \pm 0.19$ & $18.41 \pm 0.11$ & $18.20 \pm 0.16$ & $18.12 \pm 0.10$ \\
\hline \multirow{2}{*}{$\begin{array}{l}\text { TMA } \\
\text { (mg/100g flesh) }\end{array}$} & Nile tilapia & $0.95 \pm 0.05$ & $0.65 \pm 0.01$ & $0.45 \pm 0.02$ & $0.70 \pm 0.04$ \\
\hline & Catfish & $0.90 \pm 0.04$ & $0.85 \pm 0.03$ & $0.89 \pm 0.01$ & $0.91 \pm 0.02$ \\
\hline \multirow{2}{*}{$\begin{array}{l}\text { TBA } \\
\text { (mg MDA/kg flesh) }\end{array}$} & Nile tilapia & $0.80 \pm 0.01$ & $0.75 \pm 0.02$ & $0.50 \pm 0.05$ & $0.55 \pm 0.03$ \\
\hline & Catfish & $0.76 \pm 0.03$ & $0.70 \pm 0.05$ & $0.40 \pm 0.04$ & $0.45 \pm 0.02$ \\
\hline \multirow{2}{*}{$\begin{array}{l}\text { TBC } \\
\text { (log10 cfu/g sample) }\end{array}$} & Nile tilapia & $2.60 \pm 0.16$ & $2.65 \pm 0.62$ & $2.50 \pm 0.22$ & $2.50 \pm 0.13$ \\
\hline & Catfish & $2.75 \pm 0.11$ & $2.80 \pm 0.14$ & $2.70 \pm 0.31$ & $2.90 \pm 0.19$ \\
\hline
\end{tabular}

\section{Discussion}

Physicochemical characteristics of water are important parameters as they may directly or indirectly affect its quality and consequently its suitability for the distribution and production of fish and other aquatic animals and considered as the most important principles for the nature, quality and type of the water for any aquatic ecosystem
(Abdo, 2004, Ekubo and Abowei, 2011 and Moses, 1983). Electrical conductivity is a measure of the ability of water to conduct an electrical current (Entz, 1973). The values of electrical conductivity in the three lakes of the present work were higher than those of freshwater. The obtained results are in parallel with those reported by 
Abdel-Satar (2001 and 2005) and Abdo (2004, 2006) who classified Abu Za'baal lakes water as brackish one.

$\mathrm{pH}$ is a measure of whether water is acidic or basic (Ekubo and Abowei, 2011). The decrease in $\mathrm{pH}$ values during cold period, is mainly related to the high bicarbonate content, while the uptake of carbon dioxide by phytoplankton decrease as a result of increasing the concentration of bicarbonate (Abdel-Satar, 2005 \& ElWakeel and Wahby, 1970). The present results agree with that reported by (Abd-Ellah, 2003 and Abdo, 2004, 2006).

The amount of dissolved oxygen in water is very important for aquatic organisms which affect growth, survival, distribution, behavior and physiology of other aquatic organisms (Solis, 1988). The reduction in dissolved oxygen content may be due to decomposition of suspended organic matter of sewage in water (Tayel, et al., 2007).

Biochemical oxygen demand is used as a measure of the quantity of oxygen required for oxidation of biodegradable organic matter present in water by aerobic and anaerobic biochemical action (Ekubo and Abowei 2011). The highest values of BOD during hot period may be attributed to the photosynthetic activity and abundance of phytoplankton, especially in summer (Abdo 2002 and 2004). However, the increase in COD during hot period is mainly referred to the increase in the air and water temperatures, facilitating the decomposition and oxidation of organic matter (Abdo 2002, 2005 and 2006).

Heavy metal concentrations in lakes water were found in the following order: $\mathrm{Mn}>\mathrm{Pb}>\mathrm{Zn}>\mathrm{Cu}>\mathrm{Cd}$. The maximum mean values of $\mathrm{Mn}, \mathrm{Cd}$ and $\mathrm{Pb}$ exceeded the permissible limits (Table, 2). The highest levels of heavy metals in water were found during summer, while the lowest values occurred during winter. Similar results were obtained by Bahnasawy and Khidr, (2011), Ibrahim and Omar, (2013) \& Nwabueze and Oghenevwairhe, (2012). The high levels of $\mathrm{Pb}$ in water could be attributed to industrial and agricultural discharges as well as from dust which holds a huge amount of lead from the combustion of petrol in various vehicles (Hardman, et al., 1994 and Mason, 2002). On the other side, the seasonal variations of heavy metals concentrations in water may be due to the fluctuation of the amount of agricultural drainage water, sewage effluents and industrial wastes discharged into the lakes (Zyadah, 1995). Ali and Abdel-Satar (2005) attributed the increase of metal concentrations in the water during hot seasons to the release of heavy metals from the sediment to the overlying water under the effect of both high temperature and fermentation process resulting from the decomposition of organic matter.

Fish are often at the top of aquatic food chain and may concentrate large amounts of some metals from the water (Mathana, et al., 2012). Metal bioaccumulation is largely attributed to differences in uptake and depuration period for various metals in different fish species (Tawari-Fufeyin and Ekaye, 2007). Multiple factors; including seasonal, physical and chemical properties of water (Kargin, 1996 and Talab, et al., 2014), can play a significant role in metal accumulation in different fish tissues.
Heavy metals concentrations were in the following order: $\mathrm{Zn}>\mathrm{Mn}>\mathrm{Pb}>\mathrm{Cu}>\mathrm{Cd}$. It was proved that, Clarias gariepinus had higher concentrations of $\mathrm{Cu}, \mathrm{Mn}$ and $\mathrm{Pb}$ than Oreochromis niloticus. The seasonal accumulation of all heavy metals were higher in summer, spring, autumn and winter. Their levels were significantly higher in fish muscles during summer which might be due to the increased metabolism as a result of high temperature. The low concentration of $\mathrm{Cd}$ might be due to its low tendency to bioaccumulation or good ability to it's excreting from the body (Saeed, 2013).

These results agree with Ibrahim et al., (2008) who reported that, fish caught during spring and summer seasons were more influenced by heavy metals than those during autumn and winter. The levels of $\mathrm{Pb}$ were exceeded the permissible limits (Table 2).

Biochemical composition of fish muscles is a good indicator for the fish quality, the physiological condition and habitat of fish. Fish of various species do not provide the same nutrient profile to their consumer and the nutritive value of a fish varies with season. So, biochemical evaluation is necessary to ensure the nutritional value of the fish (Mathana, et al., 2012). The chemical composition of fish varies greatly from an individual of a species to another depending on starvation plus intensive food intake periods and external factors such as temperature and salinity. Variations in percentage of fat should be reflected in the percentage of water, and the two normally constitute around $80 \%$ of the fillet (Huss, 1995).

According to the present results there was a significant $(\mathrm{P}<0.05)$ difference in the moisture content between the two fish species, where Oreochromis niloticus having the highest moisture content (80.55\%), while Clarias gariepinus having moisture content of $78.45 \%$. Clarias gariepinus was superior to Oreochromis niloticus with crude protein composition of $20.54 \%$ which is significantly $(\mathrm{P}<0.05)$ different from that of Oreochromis niloticus which is $17.15 \%$. Oreochromis niloticus lipid is also significantly $(\mathrm{P}<0.05)$ different from that of Clarias gariepinus. The former has lipid content of $1.50 \%$, while the latter having $1.42 \%$ lipid. However, there was no significant $(\mathrm{P}<0.05)$ difference in their ash content.

Generally, lipid content varies within species (1.46$5.77 \mathrm{~g} / 100 \mathrm{~g})$ and is affected by the catching season (1.20$18.4 \mathrm{~g} / 100 \mathrm{~g}),($ Osman, et al., 2001). Mohamed and Gad (2005) proved that, protein and lipid contents in the tissue of Oreochromis niloticus and Clarias lazera from Abu Za'baal lakes were (15.95-15.87) and (0.96-0.99) g/100 g wet weight, respectively. Osibona et al., (2006) found that Clarias gariepinus had mean protein content of $19.64 \%$, lipid $1.15 \%$, moisture $76.71 \%$ and ash $1.23 \%$.

The results obtained are in agreement with those of Ibrahim et al., (2008) who reported that, the proximal analysis of tilapia fish muscles caught from Abu Za'baal lakes during different seasons ranged between 79.52$80.23 \%$ moisture, $16.71-17.56 \%$ protein, $1.18-1.83 \%$ lipid and $0.94-1.55 \%$ ash content (on wet wt. basis). Also, Bouriga et al., (2012) found that lipid and protein contents in fresh muscles of tilapia were 4.24 and $17.36 \mathrm{~g} / 100 \mathrm{~g}$, 
respectively. The highest level of protein during winter may be due to the increase of plankton concentration in the lakes. The amount of lipid in fish muscles is increasing prior to reproduction and decreasing during the spawning period. There is an inverse ratio between lipid and water, thus water content increased after the finishing of spawning period (Tulgar and Berik, 2012). Ibrahim et al., (2008) stated that, the quality criteria of tilapia species muscles caught during different seasons from Abu Za'baal lakes were as follows: $\mathrm{pH}$ range (6.70-7.21); TVB-N (16.0017.50) mg/100g; TMA (0.57-1.27) mg/100g; TBA (0.501.73) $\mathrm{mg}$ malonaldhyde/kg and total viable count TVC (2.08-4.29) $\log _{10} \mathrm{cfu} / \mathrm{g}$ sample. In catfish, $\mathrm{pH}$ values have been reported ranging between 6 and 7 under different storage conditions, fluctuations during this period do not provide significant variations in degradation processes, but must correlate with the biochemical, microbiological and sensory analyses (Pacheco, et al., 2010).

The results indicated that the present level of the examined heavy metals in water and fish muscles from Abu Za'baal lakes did not exhibit any effect on proximate composition and physicochemical characteristics of fish muscles. This result is in agreement with (Abdo, 2006, Ibrahim et al., 2008 \& Mohamed and Gad 2005).

\section{Conclusion}

The present study revealed that the heavy metals concentrations in water and the two fish species from Abu Za'baal lakes were affected by seasons, as summer season concentrations were significantly higher than other season's concentrations. Moreover the heavy metals concentrations especially $\mathrm{Mn}, \mathrm{Cd}$ and $\mathrm{Pb}$ in water exceed the permissible levels, while $\mathrm{Pb}$ only exceed the permissible levels in fish. The present levels of tested heavy metals in water and fish had no effects on chemical composition and biochemical quality aspects of fish.

\section{References}

Abd-Ellah, R.G. (2003). On physical limnology of Abu Zabaal Lakes, Egypt. Bull. Nat. Inst. Oceanogr. Fish. A.R.E. 29: 461-471.

Abdel-Satar, A. M. (2001). Environmental studies on the impact of the drains effluent upon the southern sector of Lake Manzalah. Egypt. J. Aquat. Biol. and fish., 5 (3): 17-30.

Abdel-Satar, A. M. (2005). Water quality assessment of River Nile from Idfo to Cairo. Egyptian J. of Aquat. Research., 31(2): 200-223.

Abdo, M. H. (2002). Environmental studies on Rosetta branch and some chemical applications at the area extends from El- Kanater El-Khyria to Kafr-El-Zyat City. Ph.D. Thesis, Fac. of Sci., Ain Shams Univ., Cairo, Egypt.

Abdo, M. H. (2004). Environmental studies on the River Nile at Damietta branch region, Egypt. J. Egypt. Acad. Soc. Environ. Develop., (D-Environmental Studies), 5 (2): 85-104.

Abdo, M. H. (2005). Physico-chemical characteristics of Abu Za'baal Ponds, Egypt. Egyptian J. of aquatic research, 31(2): 1-15.
Abdo, M. H. (2006). Levels of some trace metals in the water and fish flesh of common species in Abu Za'baal Ponds, Egypt. Egyptian J. of aquatic research, 32(2): 308-320.

Agrama, A.A., El-Sayed, E.A. (2013). Assessing and mapping water quality (case study: Western deltaEgypt). International Water Technology Journal, 3 (3), 158-169.

Al-Ghanim, Kh. A. (2012). Spatio-Temporal Distribution and Composition of Zooplankton in Wadi Hanifah Stream Riyadh (Saudi Arabia) and Abu Zabaal Lakes (Egypt). Pakistan J. Zool., 44 (3): 727-736.

Ali, M., Abdel-Satar, A. (2005). Studies of some heavy metals in water, sediment, fish and fish diets in some fish farms in El-Fayoum province. Egypt J Aquat Res., 31 (2): 261-273.

AOAC (2002). Association of Official Analytical Methods. Official Methods of Analysis. $16^{\text {th }}$ ed. Arlington, Virginia. USA.

APHA (American Public Health Association), (1998). Standard Methods for the Examination of Water and Wastewater. $20^{\text {th }}$ Edn., Washington, DC.

Authman Mohammad M.N., Wafaa, T. Abbas, Alkhateib Y. Gaafar (2012). Metals concentrations in Nile tilapia Oreochromis niloticus (Linnaeus, 1758) from illegal fish farm in Al-Minufiya Province, Egypt, and their effects on some tissues structures. Ecotoxicology and Environmental Safety 84: 163-172

Bahnasawy, M., Khidr, A.N. D. (2011). Assessment of heavy metal concentrations in water, plankton, and fish of Lake Manzala, Egypt. Turk J Zool, 35 (2): 271-280.

Bouriga, N. , Ben Ismail, H. , Gammoudi, M. , Faure, E., Trabelsi, M. (2012). Effect of Smoking-method on Biochemical and Microbiological Quality of Nile Tilapia (Oreochromis niloticus). American Journal of Food Technology, 7 (11): 679-689.

Dudka S, Adriano DC. (1997). Environmental impact of metal ore mining and processing: a review. Journal of Environmental Quality 26, 590-602.

Egyptian Ministry of Water Resources and irrigation, law 48/1982, Protection of the River Nile and Waterways from Pollution "Decree No. 49" (2013) in the amended executive regulations of the law by Minister Decision No. 92/2013. (Arabic Edition).

Ekubo, A. A., Abowei, J.F.N. (2011). Review of Some Water Quality Management Principles in Culture Fisheries. Research Journal of Applied Sciences, Engineering and Technology 3 (12): 1342-1357.

El-Wakeel, S. K., Wahby,S. D. (1970). Hydrography and chemistry of Lake Manzalah, Egypt, Arch. Hydrobiol., 67: 173-200.

Entz, B. A. G. (1973). The morphology of Lake Nasser, Lake Nasser development center, RPA, UNDPISF, FAO Aswan, Egypt, 1-18.

FAO, (2009). State of World Fisheries and Aquaculture SOFIA -2008 (p.176). Fisheries and Aquaculture Department. Food and Agriculture Organisation of the United Nations, Rome 
Ghannam, H. E.,El Haddad, E.S.E., Talab, A.S. (2015). Bioaccumulation of heavy metals in tilapia fish organs. Journal of Biodiversity and Environmental Sciences. 7(2): 88-99.

Hardman, D. J., Mceldowney, S., Watte, S. (1994). Pollution, ecology and biotreatment. Longman Scientific, Technical, England, 322 pp.

Huss, H. H. (1995). Quality and quality changes in fresh fish. FAO Fisheries Technical Paper No. 348, Food and Agriculture Organization (FAO) of the United Nations, Rome, Italy.

Huss, H. H., Ababouch, L., Gram, L. (2003). Assessment and Management of Seafood Safety and Quality (p 239). Rome: Food and Agriculture Organization of the United Nations. FAO Fisheries Technical Paper 444.

Huss, H. H., Ababouch, L., Gram, L. 2004. Assessment and management of seafood safety and quality. Rome Italy: FAO Fisheries technical paper No.444.

Ibrahim A. Th. A., Omar H. M. (2013). Seasonal variation of heavy metals accumulation in muscles of the African Catfish Clarias gariepinus and in River Nile water and sediments at Assiut Governorate, Egypt, Journal of Biology and Earth Sciences, 3 (2):236-248.

Ibrahim, S. M., Shalloof K. A., Salama H. M. (2008). Effect of environmental conditions of Abu-Zabal Lake on some biological, histological and quality aspects of fish. Global Veterinaria, 2 (5): 257-270.

Kargin, F. (1996). Seasonal changes in levels of heavy metals in tissues of Mullus barbatus and Sparus aurata collected from Iskenderum Gulf (Turkey). Water, Air Soil Pollut., 90: 557-562.

Mason, C. F. (2002). Biology of freshwater pollution. $4^{\text {th }}$ ed. Essex Univ. England. 387 pp.

Mathana, P., Thiravia Raj, S., Radha Krishnan Nair, C., Selvamohan, T. (2012). Seasonal changes in the biochemical composition of four different tissues of red spotted emperor Lethrinus Lentjan (Family:Lethrinidae). Annals of Biological Research, 3 (11): 5078-5082.

Meche, A., Manoela, C., Martins, B., Lofrano, E.S.N., Carey, Hardaway, J. Merchant,M. Luciano V., (2010). Determination of heavy metals by inductively coupled plasma-optical emission spectrometry in fish from the Piracicaba River in Southern Brazil. Microchem. J. 94: 171-174.

Mohamed, F.A., Gad, N.SH. (2005). Distribution of some heavy metals in tissue of Oreochromis niloticus, Tilapia zilli and Clarias lazera from Abo Zaabal Lakes and their impacts in some biochemical parameters and histological structure of some organs. Egyptian Journal of Aquatic Biological Fisheries, 9: 41-80.

Moses, B.S., (1983). Introduction to Tropical Fisheries. Ibadan University Press, UNESCO/ICSU: 102-105.

Nwabueze A., Oghenevwairhe, E. (2012). Heavy metal concentrations in the West African clam, Egeria radiata (Lammark, 1804) from mciver market, warri, Nigeria. Int J Sci Nature, 3(2): 309-315.

Osibona, A. O., Kusemiju, K., Akande,G. R. (2006). Proximate composition and fatty acids profile of the
African Catfish Clarias gariepinus Acta SATECH 3(1):1-5.

Osman, H., Suriah, A.R., Law,E.C. (2001). Fatty acid composition and cholesterol content of selected marine fish in Malaysian waters. Food Chem., 73:55-60.

Pacheco, J., Núñez, A.L., Espinoza,A. (2010). Estabilidad fisicoquímica durante el almacenamiento refrigerado de filetes de bagre dorado (Brachyplatystoma rousseauxii) ahumados y empacados con y sin vacío. Revista Científica UDO Agrícola, 10(1): 123-132.

Pedrosa-Menabrito, A., Regenstein, J.M. (1990). Shelf-life extension of fresh fish. A review. Part III. Fish quality and methods of assessment. J. Food Qual. 13:209-223.

Saeed Samir M., Maaly A. Mohammed (2012). Influence of Physico-Chemical Characteristics of Water on Metals Accumulation in Water and Tilapia Zillii Inhabiting Different Habitats in Egypt. Journal of the Arabian aquaculture society, 7 (1), 29-50.

Saeed, M. S. (2013). Impact of environmental parameters on fish condition and quality in Lake Edku, Egypt. Egypt. J. Aquat. Biol. and Fish., 17 (1): 101-112.

Shantakumari R., Mahenderan, N. N. M. Ramasamy,A. K. (2012). Effects of climate changes on dissolved heavy metal concentrations among recreational park tributaries in Pahang, Malaysia. Biomedical Research, 23 (1): 23-30

Solis, N.B. (1988). The Biology and Culture of Penaeus Monodon. Department Papers. SEAFDEC Aquaculture Department, Tigbouan, Boilo Philippines, 3-36.

Talab A.S., Jahin H. S., Gaber S. E., Ghannam H. E. (2014). Influence of modern cooking techniques on heavy metals concentrations of some freshwater fish fillets. Research Journal of Applied Sciences, Engineering and Technology 8 (1): 69-75.

Tawari-Fufeyin, P., Ekaye,S. A. (2007). Fish species diversity as indicator of pollution in Ikpoba river, Benin City, Nigeria. Rev. Fish Biol. Fisheries, 17: 2130.

Tayel, S.I., Ibrahim , S.A., . Authman , M.M.N, ElKasheif, M.A. (2007). Assessment of Sabal drainage canal water quality and its effect on blood and spleen histology of Oreochromis niloticus. African Journal of Biological Sciences, 3(1): 97-107.

Tulgar, A., Berik,N. (2012). Effect of Seasonal Changes on Proximate Composition of Red Mullet (Mullus barbatus) and Hake (Merluccius merluccius) were Catched from Saroz Bay. Research Journal of Biology, 02 (02): 45-50.

WHO (World Health Organization), (1993). Evaluation of Certain Food Additives and Contaminants (Forty-first report of the joint FAO/WHO Expert Committe on Food Additives). Geneva, WHO Technical Report Series no. 837.

WHO (World Health Organization), (2011). Iron, Zinc, Copper, Manganese, Cadmium and Lead in drinkingwater. Guidelines for drinking-water quality, Geneva.

Zyadah, M.A. (1995). Environmental impact assessment of pollution in Lake Manzalah and its effect on fishes. Egypt: El-Mansoura University, 127 p. 